Article

\title{
Recent Trends and Long-Range Forecasts of Water Resources of Northeast Iraq and Climate Change Adaptation Measures
}

\author{
Nahlah Abbas ${ }^{1}$, Saleh A. Wasimi ${ }^{1}$, Nadhir Al-Ansari ${ }^{2, * \mathbb{C}}$ and Sultana Nasrin Baby ${ }^{3}$ \\ 1 School of Engineering \& Technology, Central Queensland University, Melbourne, VIC 3000, Australia; \\ n.abbas@cqu.edu.au (N.A.); s.wasimi@cqu.edu.au (S.A.W.) \\ 2 Department of Civil, Environmental and Natural Resources Engineering, Luleå University of Technology, \\ 97187 Luleå, Sweden \\ 3 Department of Geospatial Sciences, RMIT University, Melbourne, VIC 3000, Australia; \\ Nasrin.Sultana@whittlesea.vic.gov.au \\ * Correspondence: nadhir.alansari@ltu.se; Tel.: +46-920491858
}

Received: 25 September 2018; Accepted: 31 October 2018; Published: 2 November 2018

\begin{abstract}
Iraq has been experiencing water resources scarcity, and is vulnerable to climate change. Analysis of historical data revealed that the region is experiencing climate change to a degree higher than generally reported elsewhere. The relationship between climate change and its effect on water resources of a region has been sparsely addressed in published literature. To fill that gap this research work first investigates if there has been a significant change in climate in the region, which has been found to be true. In the next stage, the research projects future climatic scenarios of the region based on six oft-used General Circulation Model (GCM) ensembles, namely CCSM4, CSIRO-Mk3.6.0, GFDL-ESM2M, MEROC5, HadGEM2-ES, and IPSL-CM5A-LR. The relationship between climate change and its impact on water resources is explored through the application of the popular, widely used SWAT model. The model depicts the availability of water resources, classified separately as blue and green waters, for near and distant futures for the region. Some of the findings are foreboding and warrants urgent attention of planners and decision makers. According to model outputs, the region may experience precipitation reduction of about $12.6 \%$ and $21 \%$ in near (2049-2069) and distant (2080-2099) futures, respectively under RCP8.5. Those figures under RCP4.5 are $15 \%$ and $23.4 \%$, respectively and under RCP2.6 are $12.2 \%$ and $18.4 \%$, respectively. As a consequence, the blue water may experience decreases of about $22.6 \%$ and $40 \%$ under RCP $8.5,25.8 \%$ and $46 \%$ under RCP 4.5 , and $34.4 \%$ and $31 \%$ under RCP2.6 during the periods 2049-2069 and 2080-2099, respectively. Green water, by contrast, may reduce by about $10.6 \%$ and $19.6 \%$ under RCP 8.5 , by about $14.8 \%$ and $19.4 \%$ under RCP 4.5 , and by about $15.8 \%$ and $14.2 \%$ under RCP2.6 during the periods 2049-2069 and 2080-2099, respectively. The research further investigates how the population are adapting to already changed climates and how they are expected to cope in the future when the shift in climate is expected to be much greater.
\end{abstract}

Keywords: climate change; SWAT model; general circulation model; Iraq

\section{Introduction}

Climate change occurs naturally, but during the last century global warming has been so rapid that it cannot be attributed to natural causes alone [1]. It is now believed that anthropogenic activities such as burning of fossil fuel and land cover conversion (e.g., deforestation) have led to increase in greenhouse gases-elevated $\mathrm{CO}_{2}$ concentrations and other greenhouse gases (e.g., $\mathrm{CH}_{4}, \mathrm{~N}_{2} \mathrm{O}$, etc.) have the potential by modifying radiative forcing to cause global warming, which is assumed to have started since the industrial revolution of 1850. Many research works indicate that global warming is 
highly likely to cause climate shifts [2]. Based on observed and modelled data, it has been established that elevated $\mathrm{CO}_{2}$ concentration and climate shifts would impact considerably hydrological cycles mainly through the alteration of evapotranspiration and precipitation [3-6]. Changes in rainfall intensity and volume from the historical normal have been observed since the last century and if the trend continues, there would be more frequent manifestations in the future of precipitation extremes, both dry and wet, that are of major concern due to their potential to cause damage [7]. The dry or wet extremes often cause severe droughts or major floods, respectively, imparting greater variability in river discharge and soil moisture [8] having far reaching environmental consequences.

The northeast Iraq, which includes autonomous Kurdistan, is regarded to have adequate freshwater, but due to high spatial and temporal variability, and accessibility issues owing to lack of proper infrastructure, water scarcity is widespread in the region. Freshwater availability is of critical importance for food security, public health, and environment protection in the region, but detailed information on water resources and water scarcity is very limited [9] to plan adequately. An important aspect of planning is conformity of strategies to the social and cultural norms and expectations of the population. There is an imperative to use all available information for a coherent and thorough assessment of water resources of the region, and some data exist in disperse and disparate sources, which hitherto have not been used in planning [10]. This study attempted to collate and work with all available data obtained through literature survey and contacting government and local agencies.

Typically, the quantity and quality of water resources in a basin is impacted by a multitude of factors such as precipitation and other meteorological variables, vegetation and other land cover, natural calamities such as hurricanes and earthquakes, and induced catastrophes such as bushfires. Changes in the quantity and quality of water can also occur with changes in population, climate and land use with alteration in supply and demand at a local scale, which may not be adequately reflected when aggregated at the national scale [11]. Changes also can be unprecedented because the water system could be vulnerable to climate change outside the range of historical events [12]. Climate change has the potential to impact the hydrological cycle through the alteration of evapotranspiration and precipitation [6]. Population density [13] can influence both at micro and macro levels.

Falkenmark [14] first introduced the concept of blue water and green water. Blue water is water which humans can directly access such as streamflow and groundwater. Green water is water which humans cannot directly access such as evapotranspiration and soil moisture but it is useful for vegetation and agriculture. The blue/green water notion has provided fresh ideas and new methodologies for water resources management in several regions especially in arid and semi-arid regions where water stress is severe due mainly to increased socioeconomic development and population growth. Blue/green concept can assist in supporting sustainable and equitable water resources management [15].

For this study five popular models were initially investigated which are CREAMS [16], AGNPS [17], WEPP [18], EUROSEM [19], and SWAT [20]. After a careful review of the capabilities, SWAT (Soil \& Water Assessment Tool) 2012 model was chosen to simulate blue/green water. SWAT is a physics-based distributed model well recognized for the analysis of the impacts of land management practices on water, sediment, agriculture, and non-point pollution in large complex watersheds [21]. Furthermore, SWAT model is capable of assessing the impacts of climate change on hydrological and biochemical cycles on a long term basis [22]. The model has been widely used in varied physiographic regions and in various parts of the world [23] including the Middle East.

The impacts of climate change in distant future are usually assessed by making forecasts through General Circulation Models (GCMs). IPCC (Intergovernmental Panel on Climate Change) in its Fifth Assessment Report envisioned four Representative Concentration Pathways (RCPs) of future greenhouse gas concentrations, which replaces the SRES (Special Report on Emissions Scenarios) proposed by IPCC in its Third Assessment Report. For brevity, this study presents results from three RCPs-low (RCP2.6) which assumes sustained net negative anthropogenic GHG (Greenhouse Gases) emissions after 2070, medium (RCP4.5) which assumes stabilization without overshoot to 
$4.5 \mathrm{~W} / \mathrm{m}^{2}$ radiative forcing after 2100, and high (RCP8.5) which assumes continued anthropogenic GHG emissions. Coupled Model Intercomparison Project 5 (CMIP5) (2010-2014, Organized by the Working Group on Coupled Modelling (WGCM) of the World Climate Research Programme (WCRP), Lawrence Livermore National Laboratory, Livermore, CA, USA) uses several sophisticated GCMs for climate forecasts. In this study, six GCMs, namely CCSM4, CSIRO-Mk3.6.0, GFDL-ESM2M, MEROC5, HadGEM2-ES, and IPSL-CM5A-LR were selected for ensemble climate change projections in northeast Iraq. These models were selected because not only they are popular, but also they cover all possible scenarios. The projected temperatures and precipitation were downscaled by BCSD (Bias Correction and Statistical Downscaling) method [24].

The final component of this study analyzed feedback received from General Managers and focus groups on how the local population is currently adjusting to already manifest climate change, and how they are likely to adjust to the projected climate change in the future in the backdrop of the socio-cultural context. A General Manager in the Ministry of Water Resources heads each basin and is assisted by engineers, technicians and water monitors.

\section{Study Area}

Tigris River has five major tributaries namely Khbour, Greater Zab, Lesser Zab, Al-Adhaim and Diyala Rivers (Figure 1). These tributaries are located in the left bank of the Tigris River between latitudes $33.2^{\circ} \mathrm{N}$ and $37.3^{\circ} \mathrm{N}$ and longitudes $42.9^{\circ} \mathrm{E}$ and $46.9^{\circ} \mathrm{E}$ and have significant contributions to Tigris flow. These tributaries are shared between Iraq and Turkey or Iraq and Iran except Al-Adhaim River. The characteristics of the basin of each tributary are summarized in Table 1 . Figure 2 captures the average monthly flow regimes of each tributary measured at the basin outlet. The basin outlets are identified in Figure 1. A brief description of the basin of each tributary is provided below.

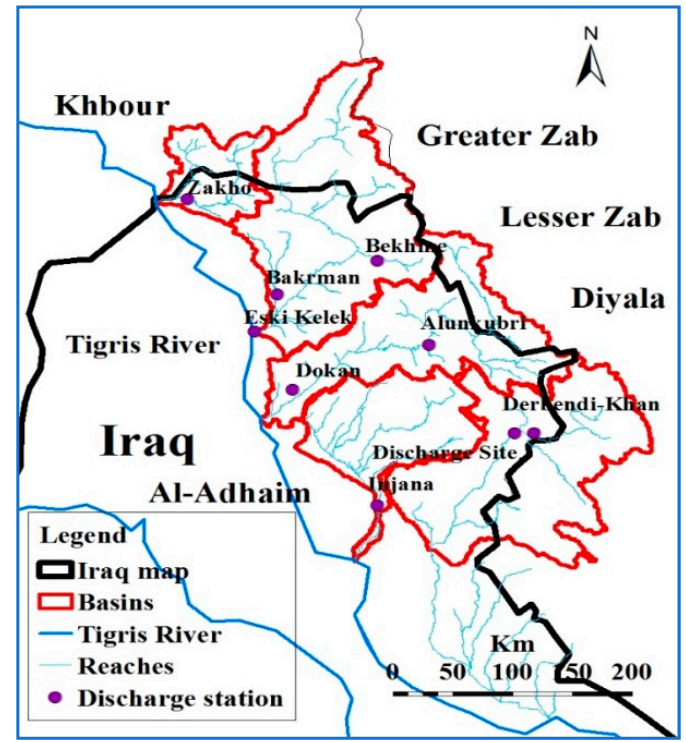

Figure 1. The location map of the study area.

Table 1. Description of the basins of the five tributaries in northeast Iraq.

\begin{tabular}{cccccc}
\hline River & Khbour & Greater Zab & Lesser Zab & Al-Adhaim & Diyala \\
\hline Basin area $\left(\mathrm{km}^{2}\right)$ & 6143 & 26,473 & 15,600 & 13,000 & 33,240 \\
Basin area shares (\%) & Iraq 43\% & Iraq 65\% & Iraq 80\% & Iraq 100\% & Iraq 75\% \\
Turkey 57\% & Turkey 35\% & Iran 20\% & $25 \%$ \\
River length (km) & 181 & 462 & 302 & 230 & 574 \\
Max annual flow (BCM) & 4.3 & 23.6 & 15.1 & 1.2 & 14.4 \\
Min annual flow (BCM) & 0.9 & 3.7 & 1.7 & 0.4 & 1.2 \\
Mean annual flow (BCM) & 2 & 12.7 & 7.8 & 0.80 & 4.6 \\
Dams & Unregulated & Unregulated & 2 & 1 & 3 \\
\hline
\end{tabular}




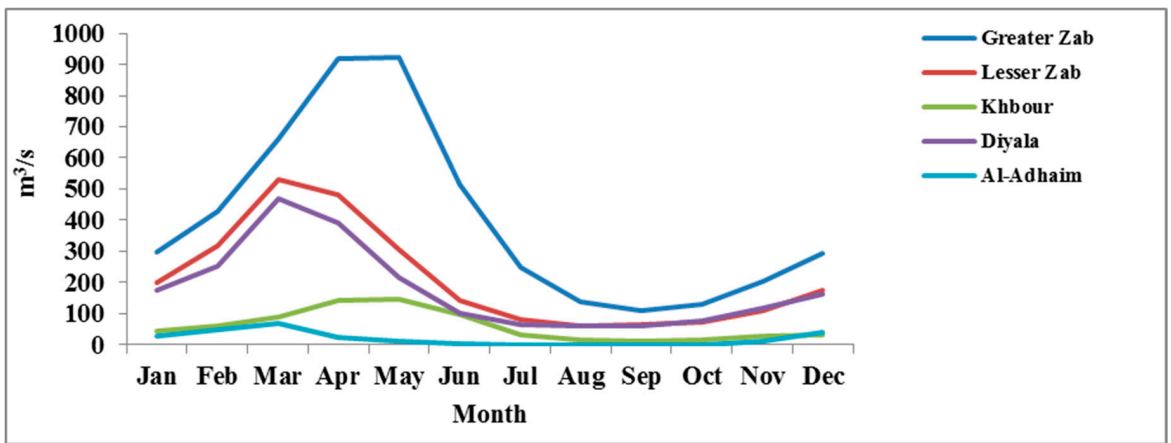

Figure 2. Average monthly flow regimes of the main Tigris River tributaries at different discharge stations (Zakho station in Khbour Basin, Eski Kalak station in Greater Zab, Dukan station in Lesser Zab, Injana station in Al-Adhaim and Derbendikhan station in Diyala) for the period from 1960 to 1990.

\section{Khbour}

Khbour River rises in Turkey from the Eastern Anatolia Region, flows south crossing the TurkeyIraq border, and then west through Zakho City before finally joining with the Tigris River. The basin is predominantly mountainous, with elevations ranging from 300 to $3300 \mathrm{~m}$ above sea level. There are many springs in the basin. Mean annual temperature is $10{ }^{\circ} \mathrm{C}$ and mean annual rainfall $780 \mathrm{~mm}$. About $60 \%$ of precipitation, including snowfall, occurs in winter and about $25 \%$ in spring. In autumn, $14 \%$ of precipitation falls as rain and $1 \%$ in summer. The basin has a typical near-natural nival regime, where precipitation in the form of snow and snowmelt in the spring are dominant. Approximately, $46 \%$ of the watershed is covered by forest, $30 \%$ by wetland, and $23 \%$ of the land are used for agricultural activities.

\section{Greater Zab}

Greater Zab originates from the Ararat Mountains in Turkey, runs through the central northern part of Iraq, and then, links with the Tigris River south of Mosul City. Greater Zab contributes about $35 \%$ of Tigris flow [10]. Greater Zab basin is also a mountainous area with elevations ranging from 180 to $4000 \mathrm{~m}$ above sea level. There are many springs in the basin, which are the main sources for irrigation. Mean annual temperature is $14.3^{\circ} \mathrm{C}$ and mean annual precipitation is $570 \mathrm{~mm}$ ranging from $350 \mathrm{~mm}$ to $1000 \mathrm{~mm}$. Typically, the distribution of rainfall over the year is $48.9 \%$ including snowfall in winter, $37.5 \%$ in spring, $12.9 \%$ in autumn, and $0.57 \%$ in summer. This is also a typical near-natural nival regime, where winter precipitation in the form of snow and snowmelt in the spring are dominant. Seventy nine percent of the watershed is covered by pasture and $21 \%$ of the land is used for different agricultural activities.

\section{Lesser Zab}

Lesser Zab (also known as Little or Lower Zab) originates from northeastern Zagros Mountains in Iran. In the upstream of the basin, the river runs through deep valleys joined by several small streams and then flows over a flat terrain before joining the Tigris River at Fatah. The climate of the basin is arid to semi-arid with wet winters and dry summers. The mean annual temperature varies from $10^{\circ} \mathrm{C}$ in the north to $22{ }^{\circ} \mathrm{C}$ in the south. The mean annual rainfall ranges from $1500 \mathrm{~mm}$ in the mountainous north to $350 \mathrm{~mm}$ in the flats of the south. Greater Zab and Lesser Zab together contribute about 50-60\% of Tigris flow. Two dams have been constructed on the river within the Iraqi part, which are Dukan and Dibis dams, for agricultural usage, hydropower, and flow regulation. About $70 \%$ of the watershed is covered by pasture and the remaining $30 \%$ is used for agriculture.

\section{Al-Adhaim}

Al-Adhaim or Nahr Al Uzaym rises in the hilly and mountainous areas within Iraq. The basin is characterized by limited rainfall and no snowfall. Therefore, the occurrence of effective flow is during 
the wet season. It links with Tigris River approximately $13 \mathrm{~km}$ downstream of Balad city. Mean annual precipitation for the Al-Adhaim basin is $200 \mathrm{~mm}$, and mean annual temperature $28^{\circ} \mathrm{C}$. Al-Adhaim flow system can be classified as an irregular flow system that is defined by precipitation occurrences. This river runs dry in summer. Approximately $71 \%$ of the basin is covered by forest and the remaining $29 \%$ by agricultural land.

\section{Diyala}

Diyala River originates in the Zagros Mountains in Iran shaping the Iran-Iraq border for more than $30 \mathrm{~km}$. Three dams have been built within Iraqi part (Derbendikhan Dam, Hemrin Dam, Diyala Weir) for multipurpose uses. With the construction of these dams, no significant influence on flow volumes and flow regime has been detected [9]. Mean annual temperature is $36{ }^{\circ} \mathrm{C}$ and mean annual precipitation is $420 \mathrm{~mm}$. The Diyala flow regime is very similar to the Lesser Zab (Figure 2). Approximately, $77 \%$ of the watershed is covered by forest and the rest $23 \%$ of the land is used for agricultural activities.

\section{Methodology}

\subsection{SWAT Model Input}

Digital elevation model (DEM), landuse map, soil map, meteorological data, and water flow data are the basic data requirements for SWAT. For this study, DEM was extracted from ASTER Global Digital Elevation Model (ASTERGDM) with a $30 \mathrm{~m}$ grid and $1 \times 1$ degree tiles (http:/ /gdem.ersdac. jspacesystems.or.jp/tile_list.jsp). The land cover map was acquired from the European Environment Agency (http:/ / www.eea.europa.eu/data-and-maps/data/global-land-cover-250m) with a $250 \mathrm{~m}$ grid raster for the year 2000. The soil map was obtained from the global soil map of the Food and Agriculture Organization of the United Nations [25]. Meteorological data which includes daily precipitation, 0.5 hourly precipitation, maximum and minimum temperatures were collected from the Iraq's Bureau of Meteorology. Monthly streamflow values were obtained from the Iraqi Ministry of Water Resources/National Water Centre. Some data were collected from local authorities. Data which did not come quality-checked were checked for quality using boxplot, and outliers for which valid explanations could not be established, were ignored.

\subsection{SWAT Model Calibration and Validation}

SWAT system is embedded within a Geographic Information System (ArcGIS interface), in which different spatial environmental data, including climate, soil, land cover and topographic characteristics can be integrated. In SWAT, the watershed is divided into sub-basins based on the digital elevation model (DEM). These are further disaggregated into Hydrologic Response Units (HRUs). HRUs are defined as packages of land that have unique distinguishable features identified by slope, soil, and land use area within the borders of the sub-basin. The HRUs represent percentages of a sub-basin area and hence are not spatially defined in the model. There must be at least one HRU in each basin. HRUs enable the user to identify the differences in hydrologic conditions such as evapotranspiration for varied soils and land uses. Routing of water and pollutants are predicted from the HRUs to the sub-basin level and then through the river system to the watershed outlet. Further detailed descriptions for each component are found in the SWAT Theoretical Documentation [22] from which the following descriptions are adopted. Two major divisions, land phase and routing phase, are enacted to simulate the hydrology of a watershed. The land phase of the hydrological cycle predicts the hydrological components including surface runoff, lateral flow, groundwater, evapotranspiration, ponds, tributary channels and return flow. The routing phase of the hydrological cycles is "defined as the movement of water, sediments, nutrients and organic chemicals through the channel network of the watershed to the outlet" [20]. In the land phase of the hydrological cycle, the simulation of the hydrological cycle is based on the water balance equation. 


$$
\mathrm{SW}_{\mathrm{t}}=\mathrm{SW}_{0}+\sum_{\mathrm{i}=1}^{\mathrm{n}}\left(\mathrm{R}_{\text {day }}-\mathrm{Q}_{\text {surf }}-\mathrm{E}_{\mathrm{a}}-\mathrm{W}_{\text {seep }}-\mathrm{Q}_{\mathrm{gw}}\right)
$$

where $S W_{t}$ is the final soil water content $(\mathrm{mm}), \mathrm{SW}_{0}$ is the initial soil water content on day $\mathrm{i}(\mathrm{mm})$, $t$ is the time (days), $R_{\text {day }}$ is the amount of precipitation on day $i(m m), Q_{\text {surf }}$ is the amount of surface runoff on day $i(\mathrm{~mm}), E_{a}$ is the amount of evapotranspiration on day $i(\mathrm{~mm}), W_{\text {seep }}$ is the amount of water entering the vadose zone from the soil profile on day $\mathrm{i}(\mathrm{mm})$, and $\mathrm{Q}_{\mathrm{gw}}$ is the amount of return flow on day i (mm).

The subdivision of basins allows the model to incorporate the differences in evapotranspiration for different crops and soils. Runoff is modelled individually for each HRU and then routed to obtain the total runoff for the basin. This increases the accuracy of the physical description of water balance. Further details of the application are available in [26,27].

To evaluate the performance of SWAT for this study, the sequential uncertainty fitting algorithm application (SUFI-2) embedded in the SWAT-CUP package [28] was used. The advantages of SUFI-2 are that it combines optimization and uncertainty analysis, it can handle a large number of parameters through Latin hypercube sampling, and the simplicity of its application. Furthermore, when compared with other different techniques used in SWAT such as Generalized Likelihood Uncertainty (GLU) estimation, Parameter Solution (ParSol), and Markov Chain Monte Carlo (MCMC), SUFI-2 algorithm was found to obtain good prediction uncertainty ranges with a few number of runs [29]. This efficiency is of great significance when implementing complex and large-scale models [21]. SUFI-2 first identifies the range for each parameter. After that, Latin Hypercube method is used to generate multiple combinations among the calibration parameters. Finally, the model runs with each combination and the obtained results are compared with observed data until the optimum objective function is achieved. SUFI-2 calculates the coefficient of determination $\left(\mathrm{R}^{2}\right)$ and the Nasch-Sutcliff efficiency (ENC) [30] to assess the goodness of fit between the measured and simulated data. $\mathrm{R}^{2}$ shows the strength of the relationship between the simulated and observed data. It ranges from zero to one. The higher values of $\mathrm{R}^{2}$ reflect less error variance, and values greater than 0.5 are satisfactory [31]. $\mathrm{R}^{2}$ has been widely used to provide an assessment of climate change detection, hydrological and hydroclimatological applications [30]. $\mathrm{R}^{2}$ is given by

$$
\mathrm{R}^{2}=\left[\frac{\sum_{\mathrm{i}=1}^{\mathrm{n}}\left(\mathrm{O}_{\mathrm{i}}-\overline{\mathrm{O}}\right)\left(\mathrm{P}_{\mathrm{i}}-\overline{\mathrm{P}}\right)}{\left[\sum_{\mathrm{i}=1}^{\mathrm{n}}\left(\mathrm{O}_{\mathrm{i}}-\overline{\mathrm{O}}\right)^{2}\right]^{0.5}\left[\sum_{\mathrm{i}=1}^{\mathrm{n}}\left(\mathrm{P}_{\mathrm{i}}-\overline{\mathrm{P}}\right)^{2}\right]^{0.5}}\right]^{2}
$$

where $\mathrm{O}_{i}$ is the observed stream flow, $\mathrm{P}_{\mathrm{i}}$ is the simulated stream flow and $\overline{\mathrm{O}}$ is the mean observed stream flow during the evaluation period and $\overline{\mathrm{P}}$ is the mean simulated streamflow.

The ENC value is an indication of how well the plot of the observed against the simulated values fits the 1:1 line. It can range from negative infinity $(-\infty)$ to one. The closer the value to one, the better the prediction is. A value of less than 0.5 indicates unsatisfactory model performance [31]. ENC is calculated as shown below:

$$
\mathrm{ENC}=1-\left[\frac{\sum_{\mathrm{i}=1}^{\mathrm{n}}\left(\mathrm{O}_{\mathrm{i}}-\mathrm{P}_{\mathrm{i}}\right)^{2}}{\sum_{\mathrm{i}=1}^{\mathrm{n}}\left(\mathrm{O}_{\mathrm{i}}-\overline{\mathrm{O}}\right)^{2}}\right]
$$

where $\mathrm{O}_{i}$ is the observed stream flow, $\mathrm{P}_{\mathrm{i}}$ is the simulated stream flow and $\overline{\mathrm{O}}$ is the mean observed stream flow during the evaluation period.

SUFI-2 enables users to conduct global sensitivity analysis, which is computed "by plotting the Latin Hypercube generated parameters against the values of the objective function using multiple linear regression analysis [32]. Then, a t-test which indicates parameter sensitivity is used to determine the relative significance for each parameter" [33] — the more sensitive the parameter, the greater is the 
t-test value [27]. In this Study, global sensitivity analysis, $\mathrm{R}^{2}$ and ENC have been evaluated to assess the SWAT model performance.

\subsection{Trends in Observed Data from Model}

Reliable data for northeast Iraq to the left bank of Tigris River is available with the Ministry of Water Resources, Iraq and with some local authorities since 1980. There has been some discontinuity in recent observations due to the war but observations prior to 2010 can be considered as reliable. Figure 3 captures the decade wise changes in the baseline period-outputs from SWAT consisting of 320 HRUs with observed data. The HRUs are identified by light grey lines in the figure, and those were delineated by SWAT when set to automatic mode. It is evident from the figures that water availability is decreasing with time. This study considers the period 1980-2010 as the baseline period for comparisons with future scenarios and reference to the baseline period in the sequel indicates the average values from 1980 to 2010 .

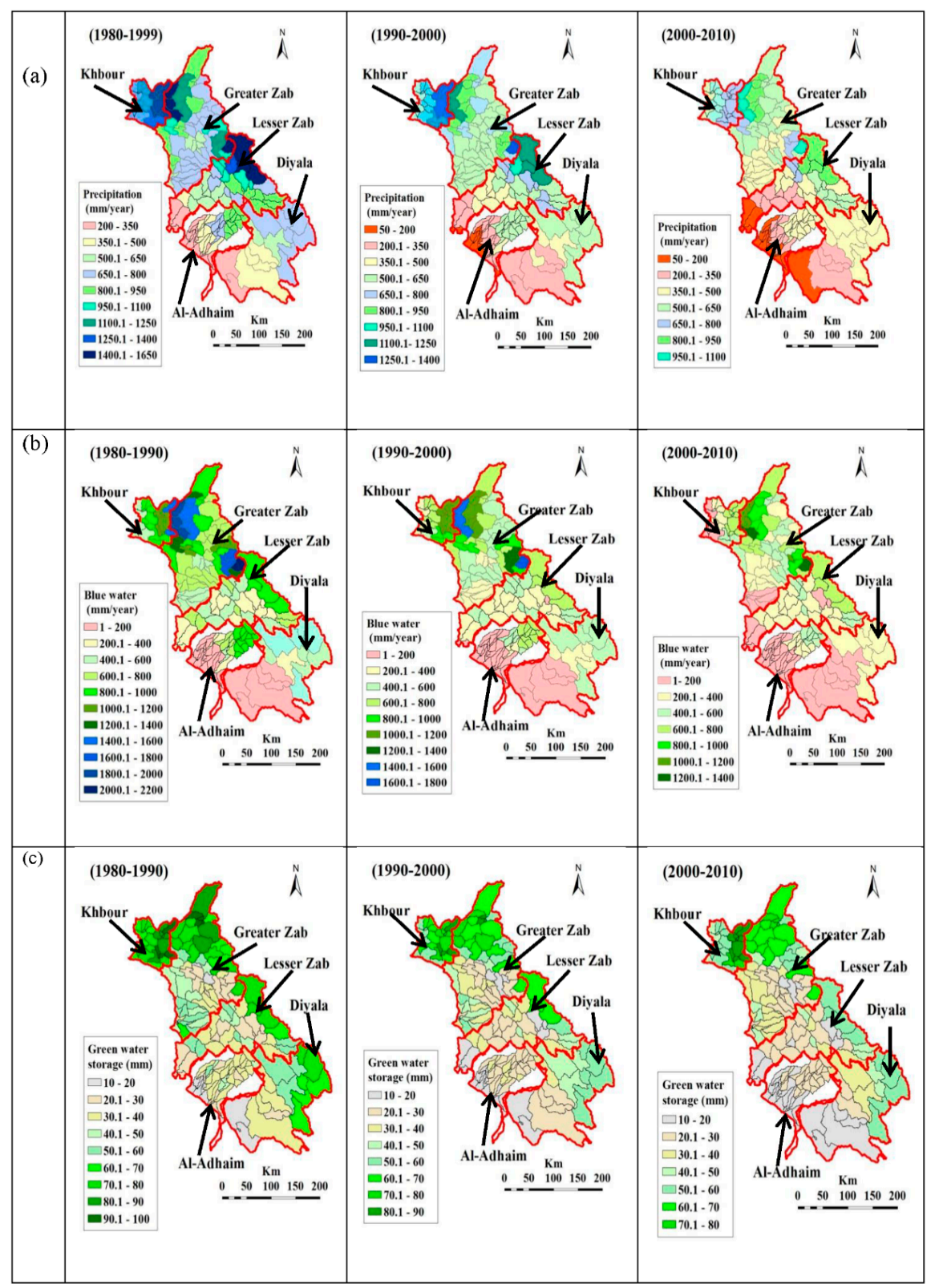

Figure 3. (a) Spatial distribution of precipitation, (b) Spatial distribution of blue water and (c) Spatial distribution of green water for the baseline period of 1980-2010 for northeast Iraq. 


\section{Results and Discussion}

\subsection{Sensitivity Analysis in SWAT}

SWAT has 25 parameters related to streamflow [20]. As is usually the practice, the first step in model calibration is to perform a sensitivity analysis of these model parameters and rank them.

The rankings of 12 highest sensitive parameters for each watershed in our study are presented in Table 2. For Khbour, Greater Zab and the upper part of Diyala, SFTMP was the most sensitive parameter; however, it was ranked eighth for Al-Adhaim and Lesser Zab. These results appear reasonable since Khbour, Greater Zab and the upper part of Diyala river are snow-dominated mountainous terrains.

Table 2. Ranks of the 12 highest sensitive parameters related to streamflow in the five basins.

\begin{tabular}{cccccc}
\hline Parameter & Al-Adhaim & Diyala & Khbour & Greater Zab & Lesser Zab \\
\hline CN2 & 1 & 3 & 2 & 4 & 1 \\
ALPHA_BF & 4 & 2 & 3 & 2 & 2 \\
SFTMP & 8 & 1 & 1 & 1 & 8 \\
SOL_AWC & 3 & 5 & 6 & 3 & 3 \\
GW_DELAY & 6 & 4 & 4 & 12 & 4 \\
ESCO & 2 & 8 & 11 & 8 & 11 \\
HRU_SLP & 7 & 11 & 12 & 5 & 7 \\
SURLAG & 5 & 12 & 10 & 7 & 5 \\
GW_REVAP & 12 & 7 & 9 & 11 & 6 \\
GWQMN & 9 & 6 & 8 & 9 & 9 \\
SLSUBBSN & 10 & 9 & 5 & 6 & 12 \\
CH_K2 & 11 & 10 & 7 & 10 & 10 \\
\hline
\end{tabular}

CN2 was the dominant SWAT calibration parameter for Al-Adhaim and Lesser Zab. However, it was ranked the second, third and fourth for Khbour, Diyala and Greater Zab, respectively. In most SWAT applications in other watersheds, CN2 has been found to be the most sensitive parameter [34]. Al-Adhaim river showed much higher sensitivity to ESCO compared to the rest of the watersheds, mainly due to the higher mean air temperature and solar radiation, which result in higher evapotranspiration losses. The identification by SWAT for the arid Al-Adhaim catchment as the most sensitive parameters to be CN2, ESCO and SOL_AWC is consistent with the report of [35] who found that SWAT model is highly sensitive to surface runoff parameters when the watershed is categorized as an arid basin.

\subsection{Calibration and Validation of SWAT}

SWAT model was calibrated for nine discharge stations distributed in the five basins. These stations are identified in Figure 1 and listed in Table 3. Table 3 also shows the period of calibration and validation for each station. The periods of validation for Zakho, Discharge Site, and Alunkubri stations were set short due to the short length of discharge data periods. The first three years in all stations were set as a warm up period.

The statistical indices for assessing the model performance at the nine discharge stations are summarized in Table 4. The values of $R^{2}$ (Coefficient of determination) ranged from 0.50 to 0.85 in the calibration process, while they were between 0.53 and 0.89 in the validation process. Apart from the Zakho station, the values of Nash-Sutcliffe Efficiency, ENC [30] index were higher than 0.50 for both calibration and validation. An ENC value of less than 0.5 indicates unsatisfactory model performance [31]. Based on the $\mathrm{R}^{2}$ and ENC values, the model performance can be judged as satisfactory when compared with the results of other investigators for other basins [33].

Among the five catchments, the model showed the best performance in Lesser Zab at Dokan station as can be seen in Figure 4a. However, the worst model performance was in Khbour catchment. There could be several reasons for inferior performance in Khbour Basin. Khbour Basin has a highly mountainous terrain characterized by varying elevations ranging from 300 to $3500 \mathrm{~m}$ above sea level. 
Also, the basin has many high discharge springs, which are important for supplying irrigation water, but discharge springs data are mostly not available to be used in the simulations. Furthermore, snowfall is a significant component in this basin (about 37\% of precipitation falls as snow). SWAT showed weakness to simulate streamflow in snowmelt months [36].

Table 3. Calibration and validation periods for each station in northeast Iraq.

\begin{tabular}{ccccc}
\hline Discharge Station & Calibration Period & From-To & Validation Period & From-To \\
\hline Zakho & 10 & $1977-1986$ & 4 & $1987-1990$ \\
Bekhme & 18 & $1979-1996$ & 8 & $1997-2004$ \\
Bakrman & 18 & $1979-1996$ & 8 & $1997-2004$ \\
Eski Kelek & 18 & $1979-1996$ & 8 & $1997-2004$ \\
Alunkubri & 8 & $1977-1984$ & 3 & $1985-1987$ \\
Dokan & 16 & $1977-1995$ & 9 & $1996-2004$ \\
Injana & 13 & $1979-1991$ & 6 & $1992-1997$ \\
Derbendi-Khan & 18 & $1979-1996$ & 8 & $1997-2004$ \\
Discharge Site & 10 & $1979-1988$ & 3 & $1989-1991$ \\
\hline
\end{tabular}

Table 4. The statistical index values ( $\mathrm{R}^{2}$ and ENC) at the nine discharge stations within the five basins of northeast Iraq.

\begin{tabular}{cccccc}
\hline \multirow{2}{*}{ Watershed } & \multirow{2}{*}{ Station } & \multicolumn{2}{c}{ Calibration } & \multicolumn{2}{c}{ Validation } \\
\cline { 3 - 6 } & & $\mathbf{R}^{\mathbf{2}}$ & $\mathbf{E N C}$ & $\mathbf{R}^{\mathbf{2}}$ & $\mathbf{E N C}$ \\
\hline Khbour & Zakho & 0.50 & 0.43 & 0.53 & 0.37 \\
Greater-Zab & Bekhme & 0.69 & 0.66 & 0.89 & 0.53 \\
Greatr-Zab & Bakrman & 0.53 & 0.50 & 0.66 & 0.52 \\
Greater-Zab & Eski Kelek & 0.58 & 0.56 & 0.84 & 0.66 \\
Lesser-Zab & Alulnkubri & 0.77 & 0.76 & 0.87 & 0.73 \\
Lesser-Zab & Dokan & 0.85 & 0.83 & 0.82 & 0.77 \\
Al-Adhaim & Injana & 0.69 & 0.67 & 0.8 & 0.76 \\
Diyala & Derbendi-Khan & 0.73 & 0.67 & 0.87 & 0.87 \\
Diyala & Discharge Site & 0.68 & 0.54 & 0.88 & 0.71 \\
\hline
\end{tabular}
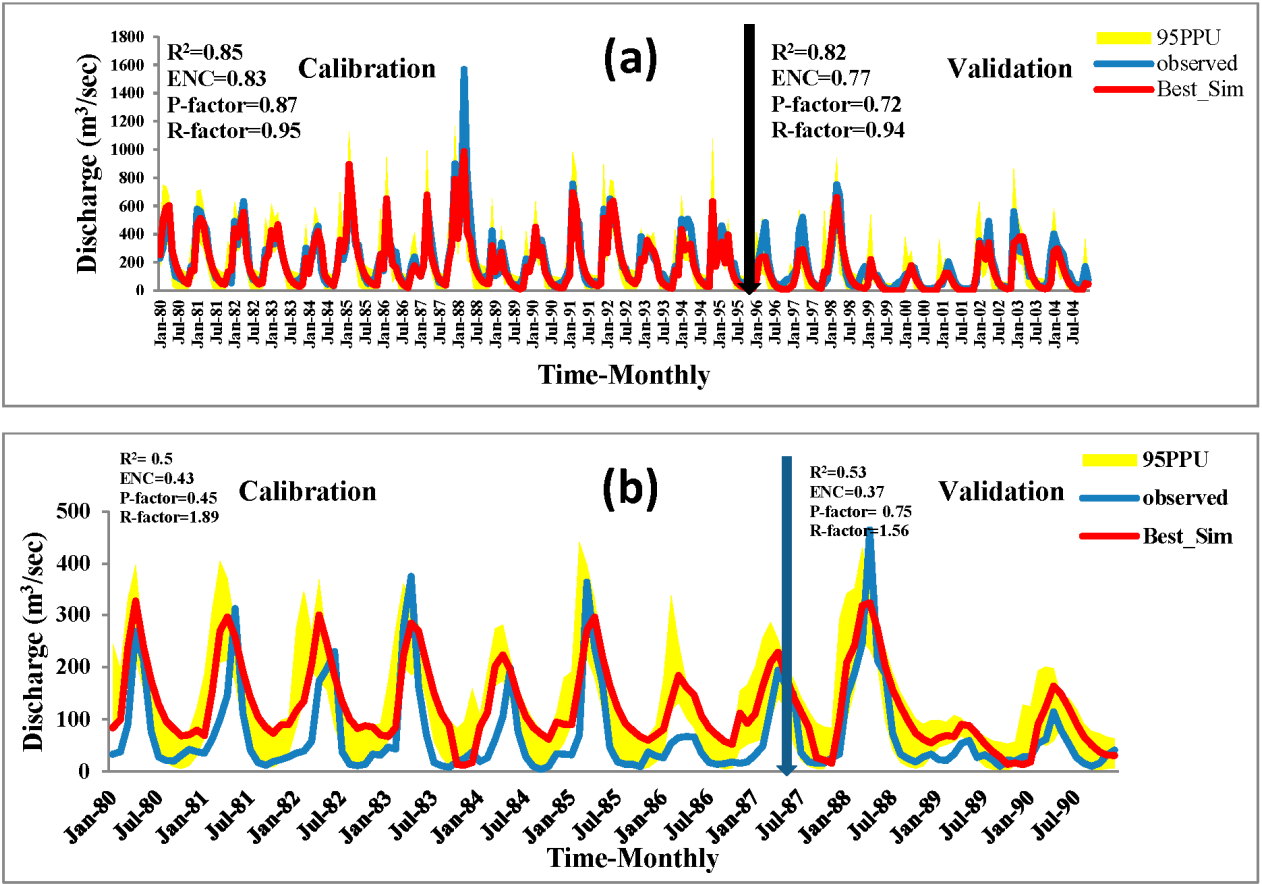

Figure 4. (a) Calibration and validation of the SWAT model at monthly scale at Dokan station in Lesser $\mathrm{Zab}$. The dark thick vertical line separates the calibration period in the left from the validation period in the right. (b) Calibration and validation of the SWAT model at monthly scale at Zakho Station in Khbour Basin. 


\subsection{Water Resources Availability}

Theoretically, water can be separated into blue water and green water [37]. Blue water is any water which can be withdrawn from water bodies such as rivers, lakes, and aquifers, whereas green water is rainwater that is stored in unsaturated zone of soil and available to plants. There is no agreed universal indicator to define water availability especially when one considers the accessibility issues. Though [37] introduced accessibility in his concept of Water Poverty Index (WPI) that includes spatial and temporal water availability, the population with access to safe water, and time and effort to collect water, the deficiencies of WPI have been identified by others [38]. Thus, in this paper we limit the definition of water availability or lack of it (water scarcity) as aggregated water availability per person for simplicity.

\subsubsection{Blue Water Availability}

Blue water availability can be used for water scarcity analysis. Among many available water scarcity indicators, a widely used indicator is the water stress threshold, which is defined as $1700 \mathrm{~m}^{3} \cdot$ capita $^{-1} \cdot$ year $^{-1}$ by [14]. This value is estimated based on household water needs, agricultural usage, industrial and energy sector consumptions, and the demand for the environment [39]. A value equal to or greater than $1700 \mathrm{~m}^{3} \cdot$ capita $^{-1} \cdot \mathrm{year}^{-1}$ is considered to be adequate to meet water needs. When water supply is below $1000 \mathrm{~m}^{3} \cdot$ capita $^{-1} \cdot$ year $^{-1}$ it is referred to as water scarcity, and below $500 \mathrm{~m}^{3} \cdot$ capita $^{-1} \cdot$ year $^{-1}$ is referred to as extreme scarcity. The water availability per capita and water stress indicators were estimated for each of the 320 HRUs using the 2.5 arcmin population map available from the Center for International Earth Science (CIESIN) Gridded Population of the World (GPW, version 3 [13] for 2005. Figure 5 provides the spatial distribution of water resources per capita per year during the period of 1980-2010. High spatial variability in the region can be attributed to two main factors, geographic and social. Due to the geographic factor blue water availability decreases from upstream mountainous areas to downstream flat areas since annual precipitation decreases from upstream to downstream. The social factor is that upstream areas are sparsely populated whereas downstream areas are densely populated with some large metropolitan areas. In general, a major part of the region is experiencing severe water scarcity.

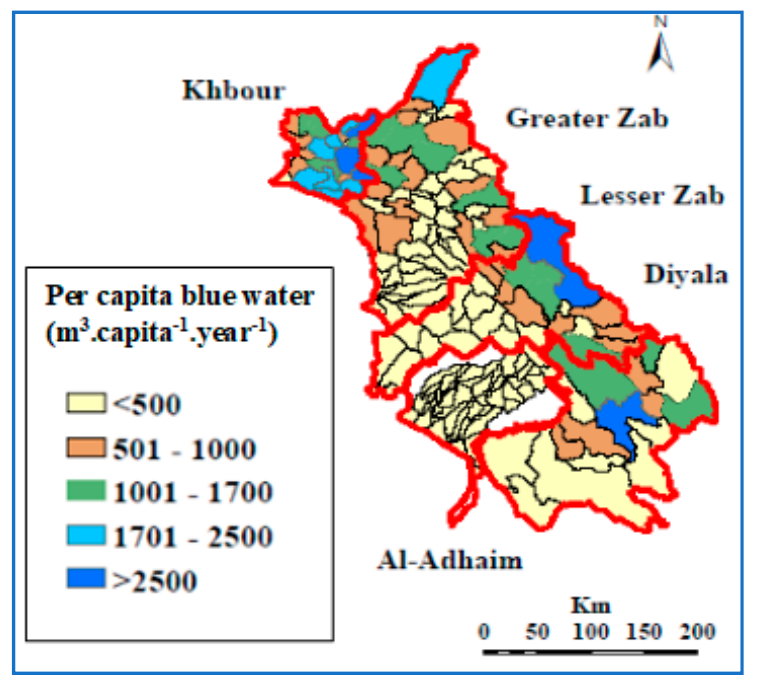

Figure 5. Water scarcity in northeast Iraq from 1980-2010 average annual blue water flow availability per capita per year using population of 2005.

\subsubsection{Green Water Storage}

Although green water is always ignored in water resources management, it plays a fundamental role in rain-fed crop productions and other environmental purposes [40]. Green water availability was 
assessed by the average of the months per year for the period of 1980 to 2010 when green water storage is available (defined as $>1 \mathrm{~mm} \cdot \mathrm{m}^{-1}$ ) and is shown in the left of Figure 6. The standard deviations (SDs) of the months per year without depleted soil water is presented for the 1980-2010 period to the right of Figure 6. The areas with high SDs can often experience reduced crop yield.

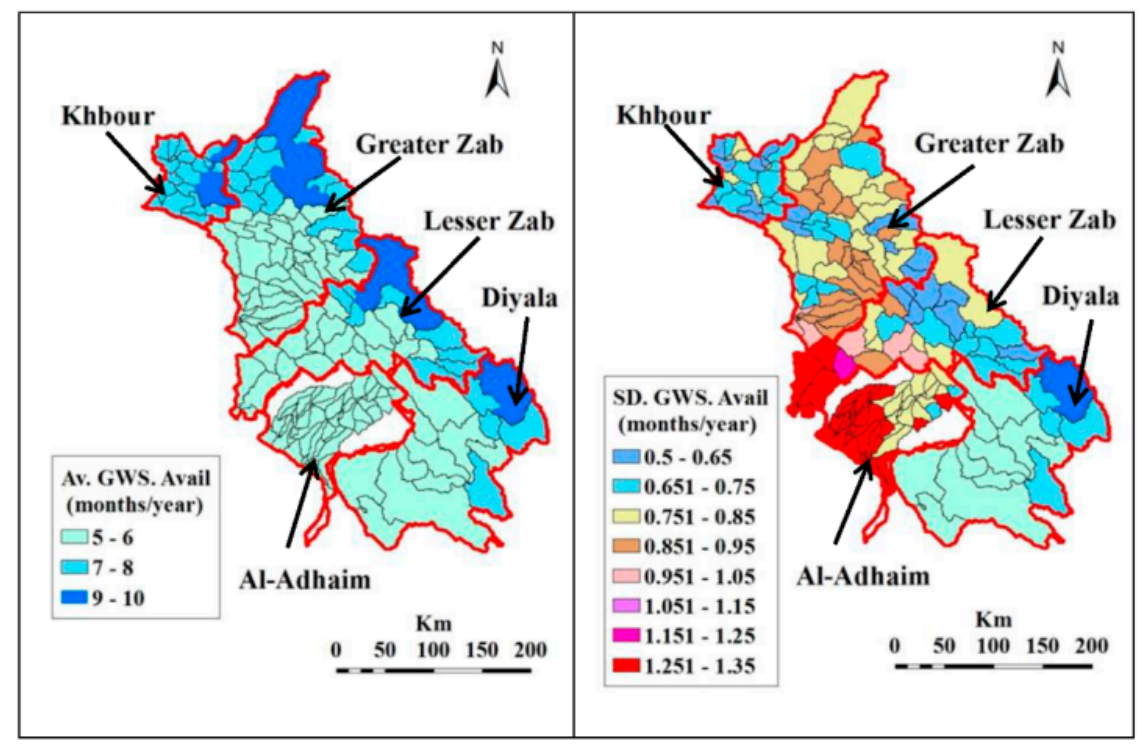

Figure 6. (Left) The 1980-2010 average green water storage (Av. GWS) and (Right) standard deviation calculated for the number of months per year where the green water storage is available (SD. GWS Avail).

\subsection{Impacts of Climate Change}

\subsubsection{Temperature Forecasts}

Table 5 captures the projected changes in mean annual temperature for two future periods 2049-2069 and 2080-2099 relative to base period 1980-2010. Changes in mean temperature forecasts are considered to be more reliable than precipitation forecasts. All the models showed consistent increasing trends in temperature. Changes in mean temperature modify evapotranspiration and precipitation and hence blue water and green water flows.

Table 5. GCMs predicted changes in the mean annual temperature of the future under RCP8.5, RCP4.5 and RCP2.6.

\begin{tabular}{ccccccc}
\hline \multirow{2}{*}{ Basin } & RCP8.5 & RCP8.5 & RCP4.5 & RCP4.5 & RCP2.6 & RCP2.6 \\
\cline { 2 - 7 } & $\mathbf{( 2 0 4 9 - 2 0 6 9 )}$ & $\mathbf{( 2 0 8 0 - 2 0 9 9 )}$ & $\mathbf{( 2 0 4 9 - 2 0 6 9 )}$ & $\mathbf{( 2 0 8 0 - 2 0 9 9 )}$ & $\mathbf{( 2 0 4 9 - 2 0 6 9 )}$ & $\mathbf{( 2 0 8 0 - 2 0 9 9 )}$ \\
\hline Khbour & 3.5 & 4.2 & 3 & 3.3 & 1.76 & 2 \\
Greater Zab & 3.5 & 4.2 & 3 & 3.3 & 1.76 & 2 \\
Lesser Zab & 4 & 3.75 & 3 & 2.8 & 2 & 2.25 \\
Al-Adhaim & 5 & 5.6 & 2.75 & 3.8 & 2 & 2.5 \\
Diyala & 5 & 5.6 & 2.75 & 3.8 & 2.5 & 2.5 \\
\hline
\end{tabular}

\subsubsection{Precipitation Forecasts}

Overall, all selected GCMs predicted a decrease in the mean annual precipitation at about half-a-century lead time (2049-2069) and about one-century lead time (2080-2099) for the five basins. Figure 7 shows the anomaly maps of precipitation distribution (maps of percent deviation from historic data, 1980-2010) for RCP2.6, RCP4.5 and RCP8.5 averaged over multi-GCM ensembles. Table 6 provides the values of expected changes in percentages. 


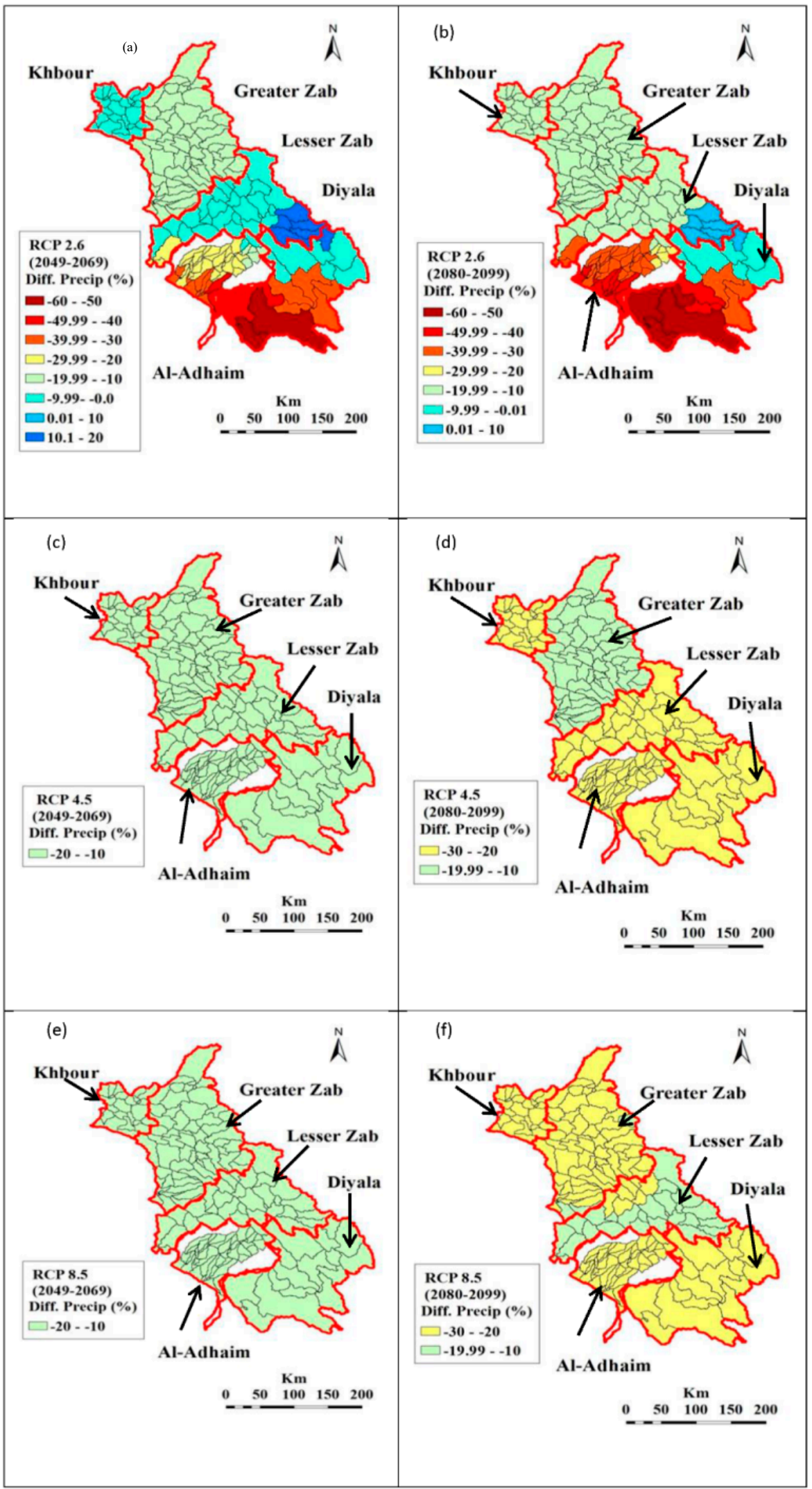

Figure 7. The impacts of climate change on the precipitation of the five basins (a) Anomaly based on scenario RCP2.6 for the period 2049-2069, (b) Anomaly based on RCP2.6 for 2080-2099, (c) Anomaly based on RCP4.5 for 2049-2069, (d) Anomaly based on RCP4.5 for 2080-2099, (e) Anomaly based on RCP8.5 for 2049-2069, and (f) Anomaly based on RCP8.5 for 2080-2099. 
Table 6. The projected relative changes in precipitation for the five basins under RCP8.5, RCP4.5, and RCP2.6 scenarios for the periods 2049-2069 and 2080-2099.

\begin{tabular}{|c|c|c|c|c|c|c|}
\hline \multirow[b]{2}{*}{ Basin } & \multicolumn{6}{|c|}{ Scenarios } \\
\hline & $\begin{array}{c}\text { RCP8.5 } \\
(2049-2069)\end{array}$ & $\begin{array}{c}\text { RCP8.5 } \\
(2080-2099)\end{array}$ & $\begin{array}{c}\text { RCP4.5 } \\
(2049-2069)\end{array}$ & $\begin{array}{c}\text { RCP4.5 } \\
(2080-2099)\end{array}$ & $\begin{array}{c}\text { RCP2.6 } \\
(2049-2069)\end{array}$ & $\begin{array}{c}\text { RCP2.6 } \\
(2080-2099)\end{array}$ \\
\hline Khbour & -12 & -25 & -18 & -25 & -7 & -15 \\
\hline Greater Zab & -12 & -22 & -17 & -15 & -12 & -15 \\
\hline Lesser Zab & -12 & -18 & -18 & -26 & -2 & -10 \\
\hline Al-Adhaim & -13 & -35 & -19 & -26 & -12 & -16 \\
\hline Diyala & -14 & -27 & -18 & -25 & -28 & -36 \\
\hline
\end{tabular}

\subsubsection{Blue Water and Green Water Forecasts}

Figure 8 captures the anomaly maps of blue water distribution (maps of percent deviation from historic data, 1980-2010) for RCP2.6, RCP4.5, and RCP8.5 scenarios for the periods 2049-2069 and 2080-2099 from the average change of the multi-GCM ensembles. Table 7 provides the estimated values as percentage changes.

Table 7. The projected relative changes in blue water for the five basins under RCP8.5, RCP4.5, and RCP2.6 scenarios for the periods 2049-2069 and 2080-2099.

\begin{tabular}{ccccccc}
\hline \multirow{2}{*}{ Basin } & RCP8.5 & RCP8.5 & RCP4.5 & RCP4.5 & RCP2.6 & RCP2.6 \\
\cline { 2 - 7 } & $\mathbf{( 2 0 4 9 - 2 0 6 9 )}$ & $\mathbf{( 2 0 8 0 - 2 0 9 9 )}$ & $\mathbf{( 2 0 4 9 - 2 0 6 9 )}$ & $\mathbf{( 2 0 8 0 - 2 0 9 9 )}$ & $\mathbf{( 2 0 4 9 - 2 0 6 9 )}$ & $\mathbf{( 2 0 8 0 - 2 0 9 9 )}$ \\
\hline Khbour & -22 & -43 & 8 & -44 & -16 & -24 \\
Greater Zab & -23 & -39 & -20 & -45 & -29 & -27 \\
Lesser Zab & -23 & -43 & -33 & -48 & -22 & -28 \\
Al-Adhaim & -23 & -48 & -35 & -49 & -70 & -65 \\
Diyala & -22 & -31 & -33 & -44 & -35 & -44 \\
\hline
\end{tabular}

In a similar analysis of green water storages, it is revealed that those may also decrease under the three scenarios for the two future periods, which are captured in Figure 9 and Table 8. Green water flow calculations (maps not shown) indicated a slight decrease in evapotranspiration due to the assumption that land cover would not significantly change from the period of 1980s to 2100s.

Table 8. The projected relative changes in green water for the five basins under RCP8.5, RCP4.5, and RCP2.6 scenarios for the periods 2049-2069 and 2080-2099.

\begin{tabular}{ccccccc}
\hline \multirow{2}{*}{ Basin } & $\mathbf{7}$ Scenarios \\
\cline { 2 - 7 } & $\mathbf{R C P 8 . 5}$ & $\mathbf{R C P 8 . 5}$ & $\mathbf{R C P 4 . 5}$ & $\mathbf{R C P 4 . 5}$ & RCP2.6 & RCP2.6 \\
& $\mathbf{( 2 0 4 9 - 2 0 6 9 )}$ & $\mathbf{( 2 0 8 0 - 2 0 9 9 )}$ & $\mathbf{( 2 0 4 9 - 2 0 6 9 )}$ & $\mathbf{( 2 0 8 0 - 2 0 9 9 )}$ & $\mathbf{( 2 0 4 9 - 2 0 6 9 )}$ & $\mathbf{( 2 0 8 0 - 2 0 9 9 )}$ \\
\hline Khbour & -9 & -18 & -12 & -16 & -5 & -7 \\
Greater Zab & -9 & -17 & -16 & -20 & -7 & -8 \\
Lesser Zab & -11 & -20 & -15 & -19 & -8 & -8 \\
Al-Adhaim & -13 & -22 & -16 & -21 & -40 & -29 \\
Diyala & -11 & -21 & -15 & -21 & -19 & -19 \\
\hline
\end{tabular}

It is rather alarming that Al-Adhaim basin, which is the driest, is likely to experience the highest reductions both is blue water and green water. Its fragile eco-system mostly dominated by forests may witness complete devastations. The next highest reduction will occur for Diyala. Diyala has very dry parts, but perhaps, it is better equipped to deal with drought than Al-Adhaim because of the dams. 


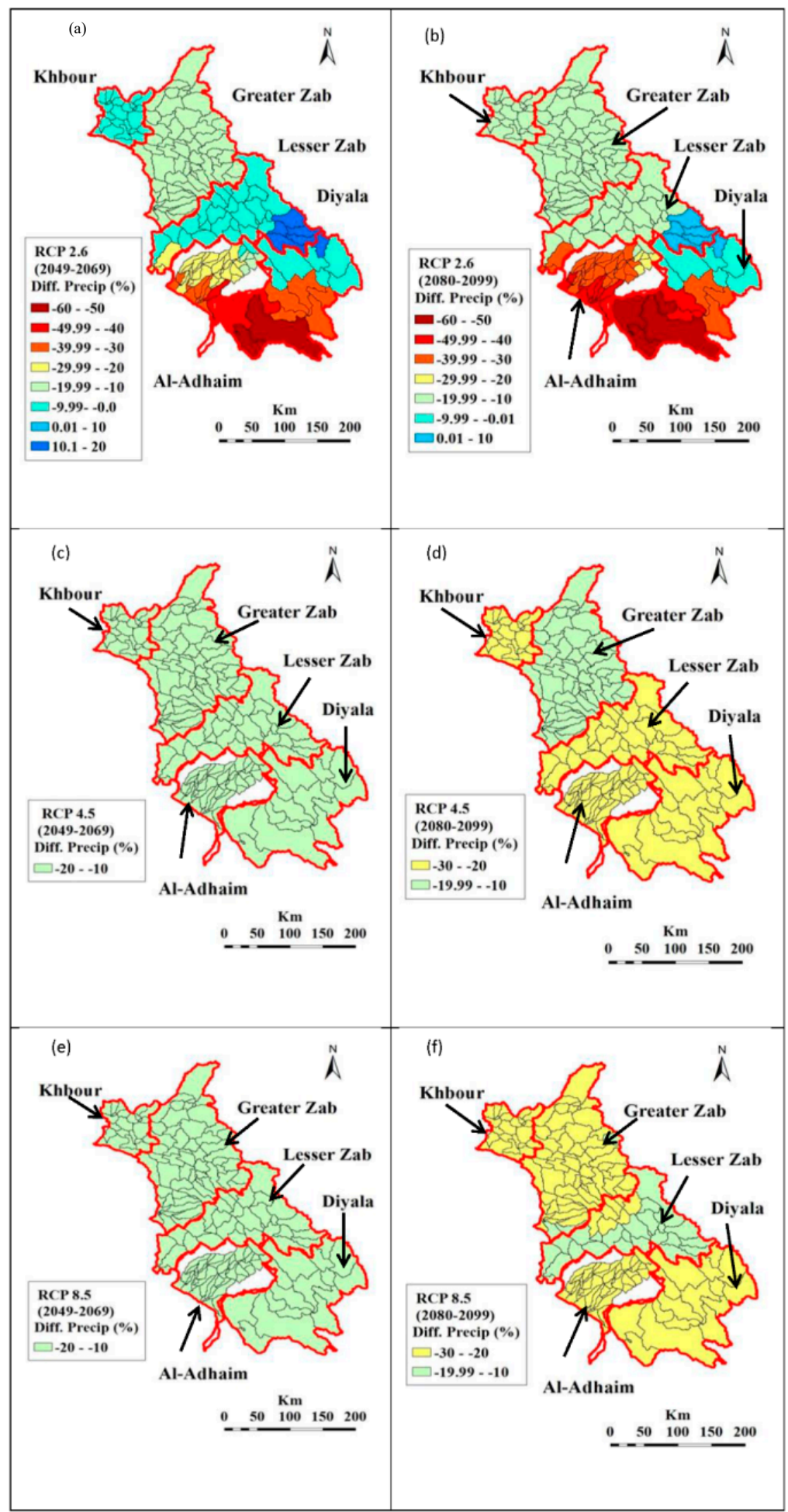

Figure 8. The impacts of climate change on the blue water of the five basins (a) Anomaly based on scenario RCP2.6 for the period 2049-2069, (b) Anomaly based on RCP2.6 for 2080-2099, (c) Anomaly based on RCP4.5 for 2049-2069, (d) Anomaly based on RCP4.5 for 2080-2099, (e) Anomaly based on RCP8.5 for 2049-2069, and (f) Anomaly based on RCP8.5 for 2080-2099. 


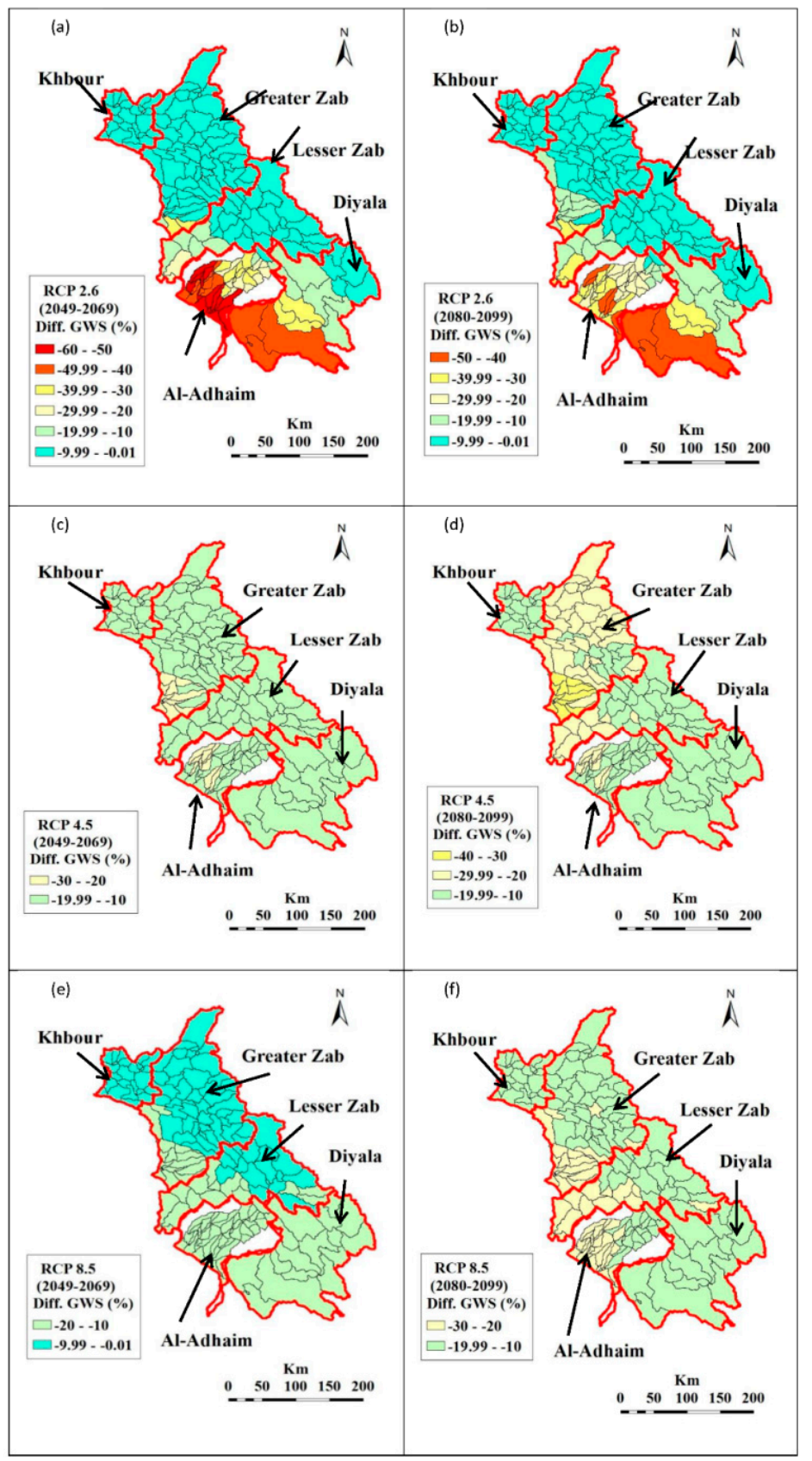

Figure 9. The impacts of climate change on the green water of the five basins (a) Anomaly based on scenario RCP2.6 for the period 2049-2069, (b) Anomaly based on RCP2.6 for 2080-2099, (c) Anomaly based on RCP4.5 for 2049-2069, (d) Anomaly based on RCP4.5 for 2080-2099, (e) Anomaly based on RCP8.5 for 2049-2069, and (f) Anomaly based on RCP8.5 for 2080-2099.

\subsection{Climate Change Adaptation}

Although climate change is a physical process linking with alterations in climatic variables, it is impacted by social processes associated with the way society evolves over time. Climate change has impacts on social, economic, and environmental systems and forms scenarios for food, water, and health security [41]. The capability of mitigating and adapting to climate change influences is dependent on proactive measures adopted by different socioeconomic groups living in differentiated geographical circumstances [42]. Climate change intensifies the vulnerability of the society. It may lead to enhanced water scarcity, exposure to diseases and undermining of growth opportunities. The impacts of climate change in northeast of Iraq will vary geographically. The south part which 
includes Diyala and Al-Adhaim are projected to be most impacted by droughts and shortened growing seasons. Extreme droughts have categorized that region in the last three decades. Severe drought has caused a reduction in agricultural production especially in the areas of rain-fed crop, which resulted in an observed reduction in farmers' income. The social dimension, which influences physical and economic dimensions, mainly boosts vulnerability to climate change. In light of the sharp decline in oil prices and the increase in terrorist operations which have led to the deterioration of the economy, institutional structures, and individual capabilities Iraq is unable to manage the current climate variability and will struggle with projected changes due to insufficient financial resources required for adaptation and mitigation.

Vulnerability in the context of climate change has three components, which are exposure, sensitivity and adaptive capacity [43]. For example, agricultural vulnerability to climate change can be described in terms of exposure to increased temperatures, decreased rainfall and thus reduction in water resources. The sensitivity of crop yields can be described through how sensitive the crops are to these changes. Adaptive capacity is defined as the ability of the farmers to adapt to the effects of this exposure and sensitivity by, for example, growing crop varieties that are more drought-resistant.

Recent studies stress the significance of socio-economic factors for the adaptive capacity of a system, especially underlining the essential role of institutions, governance and management in determining the ability to adapt to climate change [44]. The adaptive capacity of any system is fundamentally shaped by human actions and, it influences both the biophysical and social elements of a system. Generally, agricultural adaptation includes two forms of amendments in agricultural production systems. The first strategy is enhanced agricultural diversification through, for example, using drought tolerant varieties to temperature stresses. The second strategy emphasizes crop management practices, for instance, managing critical crop growth stages by not coinciding with very harsh climatic conditions such as mid-season droughts. According to [45], shifting the length of the growing period and changing planting and harvesting dates are among the common crop management practices that is used in agricultural adaptation to climate change.

For this study, focus groups of farmers were formed organized by general managers of each catchment. The discussion thread centered around farmers' perception of climate change and the adaptation measures they already have or would take to respond to the negative impacts of climate change. A majority of the farmers in the focus groups have observed that the climate has become hotter and drier, and the availability of water has decreased significantly especially in the southern region. A large proportion of farmers are poor, they suffered great adversities and have lost the resilience to face another one, and they will not be able to sustain consecutive crop losses or very low yields. Understandably, some of them have already quit farming and have moved into or seeking alternative livelihood. Farmers do not understand climate science, they cannot quantify the changes, but they can see the changes and feel the distress it is causing them. For the stability of the social fabric, it is necessary to come to the aid of the farmers. Wheat and barley are the most common crops in the region. They are winter crops. Research is needed to develop cultivars where the flowering time, the critical stage, do not synchronize with unfavorable temperatures. The process of developing desirable cultivars are discussed in [46]. However, a ready-made solution cannot be developed because climate science is not exact. A dynamic strategy is warranted, which will evolve as more information becomes available with time. Also, farmers need to be educated on crop rotation with summer crops such as corn, tomatoes, beans and potatoes. Thankfully, potato cultivation has increased manifold in the past decade.

\section{Conclusions}

The model, SWAT was applied to northeast Iraq at monthly time steps to calculate blue and green waters. The performance of the model was found to be acceptable with $\mathrm{R}^{2}$ and ENC indices as well as visual traces during the calibration and validation periods. The calibrated model was used for identifying the trends of water components in the last three decades. Precipitation and blue water 
flows were found to significantly decrease from 1980 to 2010, but green water flows were relatively stable. The latter could be due to the fact that spatial green water patterns are influenced by dominant land covers which were assumed to be unchanged for the five catchments. The model was then applied for assessing the impacts of climate change in near and distant futures under three GHG concentration scenarios (RCP2.6, RCP4.5, RCP8.5) using six GCM ensembles. All model runs under three concentration scenarios predicted that the region will be drier in the near and distant futures, albeit the five tributaries will have different responses to different emission scenarios due to differing climatic, geographic, and social factors.

These findings may have far reaching consequences because a large area already suffers from per capita water scarcity. Severe water scarcity also corresponds to areas with high population density adding more complexity to the problem. However, it is important to note that a few shortcomings could not be avoided in the study. Firstly, limited availability of data and uneven distribution of weather and discharge stations. Secondly, effects of reservoir operation, landuse changes and irrigation water usage were neglected due to limited availability of data. Thirdly, sparse evapotranspiration and soil moisture data restricted proper validation of green water flows. Fourthly, the model assumed stationary land cover for future predictions.

The feedback for climate change adaptation measures were taken from general managers who have an oversight of activities within their basin. However, it could not be confirmed if the focus groups they formed are representative of the population.

Author Contributions: Conceptualization, N.A., S.A.W., N.A.-A.; Methodology, N.A., S.A.W., N.A.-A.; Software, N.A.; Validation, N.A., S.A.W, N.A-A.; Formal Analysis, N.A., S.A.W., N.A.-A.; Investigation, N.A., S.A.W., N.A.-A.; Resources, N.A., S.N.B., Data Curation, N.A., S.N.B.; Writing-Original Draft Preparation, N.A.; Writing-Review \& Editing, S.A.W., N.A.-A.; Visualization, N.A., S.A.W., N.A.-A.; Supervision, S.A.W., N.A.-A., Project Administration, S.A.W.; Funding Acquisition, N.A.

Funding: This research forms part of the doctoral study of the first author, which was funded by the government of Iraq.

Conflicts of Interest: The authors declare no conflict of interest.

\section{References}

1. $\quad$ IPCC. Climate Change 2013: The Physical Science Basis. Contribution of Working Group I to the fifth Assessment Report of the Intergovernmental Panel on Climate Change; Cambridge University Press: New York, NY, USA, 2013.

2. Wu, K.; Johnston, C.A. Hydrologic response to climatic variability in a Great Lakes Watershed: A case study with the SWAT model. J. Hydrol. 2007, 337, 187-199. [CrossRef]

3. Pechlivanidis, I.G.; Jackson, B.M.; McIntyre, N.R.; Wheater, H.S. Catchment scale hydrological modelling: A review of model types, calibration approaches and uncertainty analysis methods in the context of recent developments in technology and applications. Global NEST J. 2011, 13, 193-214.

4. Mimikou, M.A.; Baltas, E.; Varanou, E.; Pantazis, K. Regional impacts of climate change on water resources quantity and quality indicators. J. Hydrol. 2000, 234, 95-109. [CrossRef]

5. Coffey, R.; Benham, B.; Krometis, L.-A.; Wolfe, M.L.; Cummins, E. Assessing the effects of climate change on waterborne microorganisms: Implications for EU and U.S. Water Policy. Int. J. Hum. Ecol. Risk Assess. 2014, 20, 724-742. [CrossRef]

6. Xuan, Z.; Chang, N.B. Modeling the climate-induced changes of lake ecosystem structure under the cascade impacts of hurricanes and droughts. Ecol. Model. 2014, 288, 79-93. [CrossRef]

7. Delpla, I.; Jung, A.-V.; Baures, E.; Clement, M.; Thomas, O. Impacts of climate change on surface water quality in relation to drinking water production. Environ. Int. 2009, 35, 1225-1233. [CrossRef] [PubMed]

8. Owor, M.; Taylor, R.G.; Tindimugaya, C.; Mwesigwa, D. Rainfall intensity and groundwater recharge: Empirical evidence from the Upper Nile Basin. Environ. Res. Lett. 2009, 4, 035009. [CrossRef]

9. UN-ESCWA; BGR. Inventory of Shared Water Resources in Western Asia. Available online: https:// waterinventory.org/ (accessed on 9 September 2017).

10. Al-Ansari, N.; Abdellatif, M.; Ali, S.; Knutsson, S. Long-term effect of climate change on rainfall in northwest Iraq. Cent. Eur. J. Eng. 2014, 4, 250-263. [CrossRef] 
11. Tong, S.T.Y.; Sun, Y.; Ranatunga, T.; He, J.; Yang, Y.J. Predicting plausible impacts of sets of climate and land use change scenarios on water resources. Appl. Geogr. 2012, 32, 477-489. [CrossRef]

12. Borgomeo, E.; Pflug, G.; Hall, J.W.; Hochrainer-Stigler, S. Assessing water resource system vulnerability to unprecedented hydrological drought using copulas to characterize drought duration and deficit. Water Resour. Res. 2015, 51, 8927-8948. [CrossRef] [PubMed]

13. Center for International Earth Science (CIESIN) Gridded Population of the World (GPW, Version 3). Available online: http:/ / sedac.ciesin.columbia.edu/gpw (accessed on 8 October 2016).

14. Falkenmark, M. The massive water scarcity now threatening Africa: Why isn't it being addressed? Ambio 1989, 18, 112-118.

15. Jansson, Å.; Folke, C.; Rockström, J.; Gordon, L.; Falkenmark, M. Linking freshwater flows and ecosystem services appropriated by people: The case of the Baltic Sea drainage basin. Ecosystems 1999, 2, 351-366. [CrossRef]

16. Knisel, W.G. CREAMS: A Field Scale Model for Chemicals, Runoff, and Erosion from Agricultural Management Systems; United States Department of Agriculture: Washington, DC, USA, 1980.

17. Young, R.A.; Onstad, C.A.; Bosch, D.D.; Anderson, W.P. AGNPS: A non-point source pollution model for evaluating agriculture watersheds. J. Soil Water Conserv. 1989, 44, 168-173.

18. Nearing, M.A.; Foster, G.R.; Lane, L.J.; Finkner, S.C. A process-based soil erosion model for USDA-water erosion prediction project technology. Trans. Am. Soc. Agric. Eng. 1989, 2, 1587-1593. [CrossRef]

19. Morgan, R.P.C.; Quinton, J.N.; Smith, R.E.; Govers, G.; Poesen, J.W.A.; Auerswald, K.; Chisci, G.; Torri, D.; Styczen, M.E. The European Soil Erosion Model, EUROSEM: A dynamic approach for predicting sediment transport from fields and small catchments. Earth Surf. Process. Landf. 1998, 23, 527-544. [CrossRef]

20. Arnold, J.G.; Srinivasan, R.; Muttiah, R.S.; Williams, J.R. Large area hydrologic modeling and assessment part I: Model development. J. Am. Water Res. Assoc. 1998, 34, 73-89. [CrossRef]

21. Schuol, J.; Abbaspour, K.C. Using monthly weather statistics to generate daily data in a SWAT model application to West Africa. Ecol. Model. 2007, 201, 301-311. [CrossRef]

22. Neitsch, S.L.; Arnold, J.G.; Kiniry, J.R.; Williams, J.R. Soil and Water Assessment Tool Theoretical Documentation; Grassland, Soil and Water Research Laboratory: Temple, TX, USA, 2005.

23. Sinnathamby, S.; Douglas-Mankin, K.R.; Craige, C. Field-scale calibration of crop-yield parameters in the Soil and Water Assessment Tool, SWAT. Agric. Water Manag. 2017, 180, 61-69. [CrossRef]

24. Maurer, E.P.; Brekke, L.; Pruitt, T.; Thrasher, B.; Long, J.; Duffy, P.; Dettinger, M.; Cayan, D.; Arnold, J.G. An enhanced archive facilitating climate impacts and adaptation analysis. Bull. Am. Meteorol. Soc. 2014, 95, 1011-1019. [CrossRef]

25. FAO. The Digital Soil Map of the World and Derived Soil Properties, Version 3.5; Food and Agriculture Organization of the United Nations: Rome, Italy, 1995.

26. Abbas, N.; Wasimi, S.A.; Al-Ansari, N. Assessment of climate change impacts on water resources of Khabour in Kurdistan, Iraq using SWAT model. J. Environ. Hydrol. 2016, 24, 1-21.

27. Abbas, N.A. The Impacts of Climate Change on Water Resources of Fitzroy River and Tigris Rivers Basins and Identification of Adaptation Measures. Ph.D. Thesis, Central Queensland University, Melbourne, Australia, 2018.

28. Abbaspour, K.C.; Yang, J.; Maximov, I.; Siber, R.; Bogner, K.; Mieleitner, J.; Zobrist, J.; Srinivasan, R. Modelling hydrology and water quality in the pre-Alpine/Alpine Thur watershed using SWAT. J. Hydrol. 2007, 333, 413-430. [CrossRef]

29. Yang, J.; Reichert, P.; Abbaspour, K.C.; Xia, J.; Yang, H. Comparing uncertainty analysis techniques for a SWAT application to the Chaohe basin in China. J. Hydrol. 2008, 358, 1-23. [CrossRef]

30. Nash, J.E.; Sutcliffe, J.V. River flow forecasting through conceptual models Part I-A discussion of principles. J. Hydrol. 1970, 10, 282-290. [CrossRef]

31. Legates, D.R.; McCabe, G.J. Evaluating the use of "goodness-of-fit" measures in hydrologic and hydroclimatic model validation. Water Resour. Res. 1999, 35, 233-241. [CrossRef]

32. Al-Mukhtar, M.; Dunger, V.; Merkel, B. Assessing the impacts of climate change on hydrology of the upper reach of the Spree River: Germany. Water Resour. Manag. 2014, 28, 2731-2749. [CrossRef]

33. Moriasi, D.N.; Arnold, J.G.; Van Liew, M.W.; Bingner, R.L.; Harmel, R.D.; Veith, T.L. Model evaluation guidelines for systematic quantification of accuracy in watershed simulations. Trans. Am. Soc. Agric. Biol. Eng. 2007, 50, 885-900. 
34. Cibin, R.; Sudheer, K.P.; Chaubey, I. Sensitivity and identifiability of stream flow generation parameters of the SWAT model. Hydrol. Process. 2010, 24, 1133-1148. [CrossRef]

35. Veith, T.L.; Van Liew, M.W.; Bosch, D.D.; Arnold, J.G. Parameter sensitivity and uncertainty in SWAT: A comparison across five USDA-ARS watersheds. Trans. Am. Soc. Agric. Biol. Eng. 2010, 53, 1477-1486.

36. Tolson, B.A.; Shoemaker, C.A. Cannonsville reservoir watershed SWAT2000 model development, calibration and validation. J. Hydrol. 2007, 337, 68-86. [CrossRef]

37. Sullivan, C. Calculating a Water Poverty Index. World Dev. 2002, 30, 1195-1210. [CrossRef]

38. Angulo, R.; Diaz, Y.; Pardo, R. The Colombian multidimensional poverty index: Measuring poverty in a public policy context. Soc. Indic. Res. 2016, 127, 1-38. [CrossRef]

39. Rijsberman, F.R. Water scarcity: Fact or fiction? Agric. Water Manag. 2006, 80, 5-22. [CrossRef]

40. Zang, C.F.; Liu, J.; Velde, M.; Kraxner, F. Assessment of spatial and temporal patterns of green and blue water flows under natural conditions in inland river basins in northwest China. Hydrol. Earth Syst. Sci. 2012, 16, 2859-2870. [CrossRef]

41. Bryan, E.; Deressa, T.T.; Gbetibouo, G.A.; Ringler, C. Adaptation to climate change in Ethiopia and South Africa: options and constraints. Environ. Sci. Policy 2009, 12, 413-426. [CrossRef]

42. Deressa, T.T.; Hassan, R.M.; Ringler, C.; Alemu, T.; Yesuf, M. Determinants of farmers' choice of adaptation methods to climate change in the Nile Basin of Ethiopia. Glob. Environ. Chang. 2009, 19, 248-255. [CrossRef]

43. Fellmann, T. The assessment of climate change-related vulnerability in the agricultural sector: Reviewing conceptual frameworks. In Building Resilience for Adaptation to Climate Change in the Agriculture Sector, Proceedings of the Joint FAO/OECD Workshop, Rome, Italy, 23-24 April 2012; Meybeck, A., Lankoski, A., Redfern, J., Azzu, N., Gitz, V., Eds.; Food and Agriculture Organization of the United Nations: Rome, Italy, 2012; pp. 23-37.

44. Adger, W.N.; Dessai, S.; Goulden, M.; Hulme, M.; Lorenzoni, I.; Nelson, D.R.; Naess, L.O.; Wolf, J.; Wreford, A. Are there social limits to adaptation to climate change? Clim. Chang. 2009, 93, 335-354. [CrossRef]

45. Orindi, V.; Eriksen, S. Mainstreaming adaptation to climate change in the development process in Uganda. Ecopolicy series no. 15, Acts Press, Nairobi, Kenya watersheds. J. Soil Water Conserv. 2005, 44, 168-173.

46. Gosal, S.S.; Wani, S.H.; Kang, M.S. Biotechnology and Crop Improvement. J. Crop Improv. 2010, $24,153-217$. [CrossRef]

(C) 2018 by the authors. Licensee MDPI, Basel, Switzerland. This article is an open access article distributed under the terms and conditions of the Creative Commons Attribution (CC BY) license (http://creativecommons.org/licenses/by/4.0/). 